\title{
Attacks on the Judiciary: Undercurrents of a Political versus Legal Constitutionalism Dilemma?
}

\section{H Kawadza*}

\section{P.E.R}

Pioneer in peer-reviewed, open access online law publications

Author

Herbert Kawadza

Affiliation

University of the Witwatersrand South Africa

Email

Herbert.kawadza@wits.ac.za

Date of submission

16 January 2017

Date published

30 May 2018

\section{Editor Prof W Erlank}

How to cite this article

Kawadza $\mathrm{H}$ "Attacks on the Judiciary: Undercurrents of a Political vVersus Legal

Constitutionalism Dilemma?" PER / PELJ 2018(21) - DOI

http://dx.doi.org/10.17159/1727-

3781/2018/v21i0a1696

\section{Copyright}

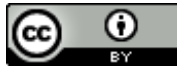

DOI

http://dx.doi.org/10.17159/17273781/2018/v21i0a1696

\begin{abstract}
A number of landmark judicial review decisions and the resultant political backlash are arguably to supportive of the claim that political and legal constitutionalism are entrenched in South Africa. The common thread in the legislature and executive's reaction to judicial review decisions is that government supremacy is under threat from legal constitutionalism. More specifically, there is a perception that courts are meddling in the political space through judgments that are aimed at weakening the government's authority and power. Nonetheless, such decisions have had an effect of reinforcing the judiciary's legal constitutional role of reviewing the lawfulness of the other branches' activities. There is need for strategies to minimize this tension as the continued antagonism can have unintended consequences such as the delegitimisation of the judiciary.
\end{abstract}

\section{Keywords}

Judicialisation; political constitutionalism; legal constitutionalism; judiciary; executive; constitution; government; politicisation. 


\section{Introduction}

Judging by myriad reports quoting fractious utterances by members of the ruling African National Congress party (ANC), it is safe to say that the recent coverage of acerbic political statements aimed at the judiciary signify a growing tension between the South African judiciary on one hand and legislature and the executive on the other. ${ }^{1}$ Several cases are illustrative of this assertion. Ultimately, the events surrounding these and many other cases discussed below had the effect of pitting those who argued that the issues were political and those who saw a need for judicial involvement. At the heart of this conflict is a debate between the starkly underlying politically motivated system of governance and of the constitutionally entrenched rights of the judiciary. For the purpose of this comment, it is the arguments proffered for and against the use of judicial review to resolve the contentious issues that are illuminating. The judgments handed down by the courts have brought into focus an arguably unsteady Executive-Legislative-Judicial relationship.

This scenario has presented an ample opportunity for re-examining the divergent theories surrounding constitutionalism in South Africa. Earlier scholarship has emphasized the need to broaden political debate on this subject with a view to reviving "serious interest in issues of deference and the separation of powers". ${ }^{2}$ In fact, the issue of the conflict between the judiciary and the other arms of the State is one in which much ink has been spilt. ${ }^{3}$ To a cynic this is an exhausted issue and would not warrant any additional scholarly consideration. However, maintaining such an attitude arguably smacks of complacency and is counterproductive to constitutionalism and good governance. Continued attention on this issue is

Herbert Kawadza. PhD (Manchester) LLM (London) PGCE (Manchester Met), LLB Hons (University of Zimbabwe). Senior Lecturer, School of Law, the University of the Witwatersrand, South Africa. E-mail: Herbert.kawadza@wits.ac.za.

1 Recent years have seen a number of important court decisions going against the ANC led government. Most of these had an effect of cementing freedoms enshrined in the Constitution, but surprisingly, such outcomes have not been accepted without vilification by the Executive. In other instances government simply ignored the court orders. See for example Primedia Broadcasting, A Division of Primedia (Pty) Ltd v Speaker of the National Assembly 20154 SA 525 (WCC); Freedom under Law v Acting Chairperson: Judicial Service Commission 20113 SA 549 (SCA); Minister of Justice and Constitutional Development $v$ The Southern African Litigation Centre 2016 ZASCA 17 (15 March 2016).

2 Democratic Governance and Rights Unit 2014 http://www.dgru. uct.ac.za/sites/default/files/image_tool/images/103/Separation\%20of\%20Powers\% 20Draft\%20August\%202014.pdf 5. See also a similar exhortation by Hoexter Administrative Law 519.

3 See among others Vinx 2010 Political Theory 809; Hirschl 2006 Fordham L Rev 721; Walen 2009 ICON 329; Hickman 2005 U Toronto LJ 981; Honohan "Republicans, Rights, and Constitutions"83. 
crucial and as Malila contends, it is "fitting that with the emerging trends, the importance of the independence of the judiciary in the systems of checks and balances ... is repeatedly examined and re-examined". ${ }^{4}$ Furthermore, the crucial social, ${ }^{5}$ economic $^{6}$ and political ${ }^{7}$ implications of constitutionalism make it imperative that discussion on this debate be kept alive. Unlike other submissions however, this discussion aims to contribute to the scholarship that has sought to situate that antagonism within the South African context. Through a panoramic interpretation of the political responses to judicial review judgments this comment seeks to make a modest attempt at exposing and revisiting the political and legal constitutionalism discourse that have spurred by such events.

This comment does not intend to dwell on the correctness or otherwise of the substantive reasoning behind the judgments but rather on their implications in this discussion. To that end, this article proceeds as follows. The second section gives a background to the legal and political constitutionalism theories and reviews the inherently non-complementary or incompatible central components of the two systems. Section three positions these concepts within the South African context. It accomplishes that by making reference to some of the cases whose outcomes illustrate the deep-seated legitimacy conflict in the trilateral relationship. It also briefly discusses the possible consequences emanating from that those hostilities. Section four concludes.

\section{Political and legal constitutionalism revisited}

Simply described, the main objective of constitutionalism is the prevention of arbitrary governance. ${ }^{8}$ This is achieved by way of elaborate structures that establish who can rule, the technique of ruling as well as the purpose. ${ }^{9}$ From this established theory two contrasting models - legal and political constitutionalism - have emerged. These two schools of thought differ in terms of their characterisation of what amounts to arbitrary conduct and the resultant strategies that are aimed at averting the perceived threats to basic tenets of constitutionalism.

Malila 2011 Zambia LJ 72.

See generally Goldoni 2012 ICON 926; Dani 2009 http://www.lse.ac.uk/europeaninstitute/Assets/Documents/LEQS-Discussion-Papers/LEQSPaper13b.pdf; Sciulli Theory of Societal Constitutionalism.

$6 \quad$ See for instance Gerber 2001 JITE 14; Feiyue 2006 Front Law China 372; Dawson, Enderlein and Joerges Beyond the Crisis.

7 Shinar Accidental Constitutionalism; Bellamy Political Constitutionalism; Tushnet 2006 Chi-Kent L Rev 992.

$8 \quad$ Arato 2012 ICON 627-659; Cohen "Sovereignty in the Context of Globalization" 261.

$9 \quad$ See for instance Horowitz "Constitutional Design" 15-36. 
The political constitution theory is premised on the notion that political processes should be mechanism through which those who exercise political power should be subjected to. In essence it provides that alleged violations of political codes or norms should be subjected to political processes ${ }^{10}$; that "political decisions should be taken by politicians", ${ }^{11}$ that "no political matter may be decided other than by the people, lest that matter (no matter how obvious or true or right) becomes a source of domination over the people". ${ }^{12}$ Adherents claim that accountability is facilitated not by the depoliticising efforts of the judiciary but by mechanisms such as elections and other motivation that compel politicians to make judgments that benefit the electorate. ${ }^{13}$ Since political matters require political remedies the judiciary has no room to adjudicate on such issues. The argument is that judicial involvement would result in the "juridification" of political issues which would culminate in taking "political decisions out of the hands of politicians and into the hands of judges". ${ }^{14}$

By contrast, proponents of legal constitutionalism submit that judicial review and not political mechanisms should be the tool for holding those exercising political power to account. ${ }^{15}$ They perceive "political life as potentially destructive of the rule of law and individual rights and which, therefore, must be constrained by judicially enforceable constitutional prescriptions". ${ }^{16}$ What seems to be the building block of legal constitutionalism is that the judicial process is more reliable and fairer than the democratic process. It is argued, among other things, that the judiciary is able isolate itself from public pressure. ${ }^{17}$ Furthermore, it is submitted that through judicial review, not only is the sanctity of the Constitution preserved but the fundamental rights of individuals are also secured. ${ }^{18}$ More recent legal constitutional scholars such as Tomkins advance the concept of "juristocracy" by which they argue that all constitutional problems can be resolved by the judiciary and in fact,

$10 \quad$ Gee and Webber 2010 OJLS 273; Griffith 1979 MLR 1-2; Waldron 2006 Yale LJ 1346.

11 Griffith 1979 MLR 2. For additional attacks on the alternative scholarship see for instance Honohan "Republicans, Rights, and Constitutions" 83; Craig "Political Constitutionalism and Judicial Review" 19; Vinx 2010 Political Theory 809; Walen 2009 ICON 329; Hickman 2005 U Toronto LJ 981.

12 Gee and Webber 2010 OJLS 273.

13 See Bellamy Political Constitutionalism.

14 Griffith 1979 MLR 16.

$15 \quad$ Gee and Webber 2010 OJLS 273; Carbonell Theory of New Constitutionalism; Hirschl 2006 Fordham L Rev 721

16 Gee and Webber 2010 OJLS 279-280.

17 See generally Bellamy Political Constitutionalism.

18 Moseneke 2012 SALJ 17. See also Budlender 2011 http://www.polity.org.za/article/sa-budlender-address-by-human-rights-lawyer-atthe-bram-fischermemorial-lecture-johannesburg-11112011-2011-11-11. 
that it is inconceivable that a constitutional problem can be said to be surely straighten out until the courts have solved it. ${ }^{19}$

Nonetheless, political constitutionalists argue that

... when it comes to making decisions about our collective life, constitutional courts...lack the intrinsic fairness and impartiality of the democratic process that of treating each person's views equally. They restrict access and unduly narrow the range of arguments and remedies that may be considered, and are neither accountable nor responsive to citizens in ways that ensure their opinions and interests receive equal concern and respect. ${ }^{20}$

\section{Furthermore, litigation}

... is a time consuming business, with constitutional courts perforce having to be highly selective as to which cases they hear. When they do so, the case is presented as a dispute between two litigants and the only persons and arguments with standing have to relate to the points of law that have been raised by those concerned. 21

Much as these schools of thought depict divergent foundational tenets which in turn make diverse requirements on the political and judicial actors, in the final analysis they all converge on their acceptance of the fact that the Constitution is higher law which invalidates all other laws that stand in conflict with it. ${ }^{22}$

\section{The South African setting}

In South Africa recognition was given to the fact

... that untrammelled parliamentary authority was vulnerable to abuse, and that this should be guarded against by entrenching certain rights against legislative interference. Once this decision was made, institutional arrangements had to be made in order to police the boundaries for legislative and executive conduct which had been created by the constitution. This role was given to the courts. ${ }^{23}$

19 Tomkins 2010 U Toronto LJ 1. See also Craig 2011 ICON 112-131. European Commission for Democracy through Law Definition and Development of Human Rights 81.

21 Bellamy 2007 https://www.ucl.ac.uk/spp/research/publications/downloads/SPP-WP26-Inaugural-Lecture.pdf. In South Africa s 2 of the Constitution of the Republic of South Africa, 1996 provides that: "This Constitution is the supreme law of the Republic; law or conduct inconsistent with it is invalid, and the obligations imposed by it must be fulfilled." Related to this is s 8, providing that all law is subject to the Bill of Rights and that the same binds the Legislature, the Executive, the Judiciary and all state organs.
Democratic
Governance
and
Rights
Unit
2014

http://www.dgru.uct.ac.za/sites/default/files/image_tool/images/103/Separation\%20 of\%20Powers\%20Draft\%20August\%202014.pdf. See also Klug 2010 CCR 1; Van Zyl 2009 PELJ 2. 
More specifically, "Courts are required by the Constitution 'to ensure that all branches of government act within the law' and fulfil their constitutional obligations. This Court 'has been given the responsibility of being the ultimate guardian of the Constitution and its values". ${ }^{24}$ As such judicial intrusion into the political realm is provided for under the constitution.

Ironically, it is that constitutional mandate itself that has driven the courts to the rough end of the political stick. This is mainly, as shown above, that role often times entails thwarting or declaring unconstitutional LegislativeExecutive decisions courts. As such the judiciary is denounced for supposedly fashioning their judgments with the objective of advancing or collusion with other entrenched interests. What emerge below are undertones of an unfolding conflict between legal and political constitutionalism.

\subsection{The trend}

After a long period of dormancy, South Africa is witnessing a resurgence of the legal and political constitutionalism controversy. ${ }^{25}$ Recent years have been associated with increased negative reports, complaints and stirring emotional statements by the ANC government against the judiciary. It is worth noting that much of the contestation follows a rise in cases that were capable of and indeed should have been resolved politically. ${ }^{26}$ That the courts got embroiled in such cases should not be surprising. Judicial involvement was a mere confirmation of the natural order of things; people fall back on the judiciary when disputes are not resolved, just as they rely on the electoral system to get rid of politicians. ${ }^{27}$

As will be shown below, a common thread in these attacks is what is perceived as judicial invasion into the political domain. The contention is that, using judicial review as a tool; courts are meddling in the political space through judgments that are designed at chipping off the government's

24 Doctors for Life International $v$ Speaker of the National Assembly 20066 SA 416 (CC) para 38.

25 It is recorded that this trend was last seen in the 1950s. See Van Zyl 2009 PELJ 3 and the authorities cited thereat. See also Siyo et al 2015 PELJ 816. This is further supported by Klaaren who notes that "Since at least around 2003, the judiciary and the government had been engaged in seriously negotiating a set of rules and principles regarding the institution of the judiciary ... This was the case at least until late 2005 and 2006, when the issue spilled into public debate". See Klaaren 2009 http://wiredspace.wits.ac.za/jspui/bitstream/10539/8749/1/Hlophe\%20and\%20the\% 20Politics\%20of\%20the\%20Judiciary.pdf. See also Albertyn 2006 SAJHR 126. Press 18 December 2011, Business Day, The Times 16 March, The New Age 27 March 2012. 
authority and powers. It is feared that the continued intrusion might blur the lines that separate the judiciary from the legislature and Executive. Political constitutionalism, especially the alleged supremacy of the political system over the courts is best manifested through a number of statements by government ministers and the ANC's spokespeople.

Several acerbic statements stand out in this regard. For instance in a show of displeasure after losing two major cases in the Constitutional Court ${ }^{28}$ the then secretary general of the ANC, Gwede Mantashe lashed at the courts for "acting as if they were the political opposition' and in so doing seeking to arrest the functioning of Government". ${ }^{29}$ In another explicit display of discontentment with the judiciary, the secretary general of the South African Communist Party (SACP), an alliance of the ruling party, Blade Nzimande ranted that South Africa was slowly gravitating towards a "judicial dictatorship" manifested through "a co-ordinated liberal offensive" aimed at attacking "almost any decision by the president and the executive". ${ }^{30}$

Probably the clearest indicator of the government's aversion of judicial review is best summarised by the President of the Republic of South Africa Mr Zuma who, in March 2012 is alleged have said: "We are a Government ... and the Judiciary is not a government and it cannot simply review all government policies. They cannot be elevated to do something they are not supposed to do". 31

Of the many incidences ${ }^{32}$ that embody the hostilities towards the judiciary, several land mark cases are illustrative. In a criminal case ${ }^{33}$ before the

28 These essentially centred on the challenge by Hugh Glenister to the scrapping of the Scorpions as well as actions instituted to prevent Mr Zuma from reappointing Judge Sandile Ngcobo as chief justice. See Glenister $v$ President of the Republic of South Africa 20113 SA 347 (CC).

Gumede Restless Nation; Hartley 2011 https://www.pressreader.com/southafrica/business-day/20111102/282480000577522. See also Legalbrief Today 2011 http://legalbrief.co.za/diary/legalbrief-today/story/zuma-lays-down-law-onseparation-of-powers/print/. News24 2011 http://m.news24.com/news24/SouthAfrica/Politics/Nzimande-slamsjudicial-dictatorship-20111217-2. News24 2011 http://m.news24.com/news24/SouthAfrica/Politics/Nzimande-slamsjudicial-dictatorship-20111217-2.

This article does not seek to revisit all the cases that have exposed this conflict. Other cases include S v Makwanyane 19953 SA 391 (CC); Government of the Republic of South Africa v Grootboom 20011 SA 46 (CC); Minister of Health v Treatment Action Campaign 20025 SA 721 (CC).

Freedom under Law v Acting Chairperson: Judicial Service Commission 20113 SA 549 (SCA). 
Constitutional Court involving the then deputy president Mr Jacob Zuma and another accused, it later alleged that before judgment was handed down Hlophe JP, separately approached some of the judges of the Constitutional Court with a view to influencing the pending judgment. Subsequently, this was reported to the other judges of the Constitutional Court and a complaint was against lodged to the Judicial Service Commission (JSC). ${ }^{34}$ Not content with the JSC's adverse findings, Mantshe made a scathing criticism of the judgment which he characterised as a conspiracy by "counter-revolutionary forces" bent on destroying the ruling party. ${ }^{35}$

To clearly put these averments in perspective and understand the hostilities, a quick review of a few landmark cases is necessary. Perhaps the case that serves as an apt demonstration of resistance against constitutional court decisions and the fact that the judiciary sometimes fails to rely on the allegiance of political partners to be in order to have their decisions enforced $^{36}$ is Minister of Justice and Constitutional Development $v$ The Southern African Litigation Centre. ${ }^{37}$

Following public outcry after the government defied the Rome Statute ordering the arrest and detention of President Al Bashir of Sudan for extensive human rights violations in his country, the government chose to cover up its inaction by portraying itself as a victim in the whole saga. The spin to the "who" debacle was that there was "a drive in sections of the judiciary to create chaos for governance; that's our view ... you always see that the narrative is totally negative and create a contradiction". ${ }^{38}$ Similarly, the Minister of Higher Education Nzimande seethed that "sections of the judiciary tend to somehow overreach into areas that one would expect even in a constitutional state to tread very, very carefully". ${ }^{39}$

$34 \quad$ For a background to this case and the subsequent academic discussion arising therefrom see S v Zuma 20062 SACR 191 (W); Hlophe v Constitutional Court of South Africa 2008 ZAGPHC 289 (25 September 2008); Dodek 2009 JPPL 121. Letsoalo, Rossouw and Alcock 2008 https://mg.co.za/article/2008-07-04-anc-bossaccuses-judges-of-conspiracy-against-zuma.

$36 \quad$ See also Mendes 2010 CCR 33.

37 Minister of Justice and Constitutional Development $v$ The Southern African Litigation Centre 2016 ZASCA 17 (15 March 2016).

38 Comrie 2015 https://www.news24.com/SouthAfrica/News/Gwede-Mantashesingles-out-problematic-courts-20150622; Britton 2015 http://702.co.za/articles/ 3355/gwede-mantashe-the-judiciary-has-anti-government-tendencies; eNCA 2015 https://www.enca.com/south-africa/gwede-mantashe-criticises-judiciary-beingproblematic.

39 Comrie 2015 https://www.news24.com/SouthAfrica/News/Gwede-Mantashesingles-out-problematic-courts-20150622; Britton 2015 http://702.co.za/articles/ 3355/gwede-mantashe-the-judiciary-has-anti-government-tendencies; eNCA 2015 


\subsection{Remarks on the tension}

The empirical accounts of hostilities towards the judiciary echo the view that legal constitutionalism is a threat to the political hegemony. With a view to countering that phenomenon, the political response has been a nuanced attempt towards the politicisation of the judiciary. This takes the form of "subtle threats and intimidation of judicial officers to force them into making findings favourable to certain political players". ${ }^{40}$ In other words, it is manifested by a "growing perception of the court as a partisan and possibly a coopted decision making body instead of an impartial and independent arbiter of conflicts". 41

The foregoing also validates the commonly held hypothesis that "constitutional adjudication has traditionally been regarded as 'political'; identifying how judicial decisions, especially those originating in the context of constitutional review, are referred to as 'political' as opposed to 'legal' or the like". ${ }^{42}$ As such, judicial review is deemed to be an intrusion into the political space and a negation of the assumption that other than political constitutionalism there is no space for any other superior norms or legal constitutions.

However, that hypothesis only serves to expose lack of appreciation of the reality that law and politics are intertwined. ${ }^{43}$ It is also a failure to acknowledge that judicial detachment to avoid conflict is "impossible of achievement therefore it ought not to be strived for". ${ }^{44}$ Such ignorance arguably explains why, instead of simply complying with or appealing against unfavourable rulings, the government has sought to portray itself as a victim and as such, seek a realignment of the judiciary. ${ }^{45}$

However in spite of such political denunciation it must be borne in mind - to the chagrin of political constitutionalists; that the judiciary will be expected to continue undeterred, to invalidate negative government policies or actions on constitutional grounds. ${ }^{46}$ The reality therefore is that "[w]here the courts are granted jurisdiction under the Constitution, they cannot decline

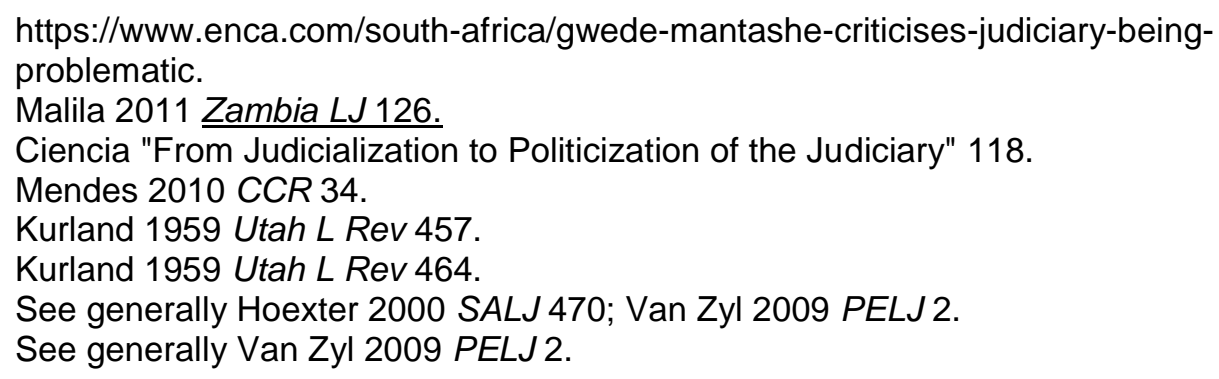


to intervene simply because there may be political consequences to the decision". ${ }^{47}$

It is not as if the court itself is not aware of the dangers of intruding in the legislative and executive territories. The recent case of the Economic Freedom Fighters $v$ Speaker of the National Assembly ${ }^{48}$ exhibits a classic scenario of self-examination and a self-criticism that demonstrates that members of the judiciary are mindful of unwarranted judicial activism that seeks tramples on the separation of powers. In the dissenting judgment the Chief Justice of South Africa, Mogoeng Mogoeng expressed disquiet with the majority's directive that the Speaker of the House of Assembly implement necessary processes and mechanisms aimed holding the President Zuma accountable for his conduct (and failures) highlighted in the report of the Public Protector.

In his admonishment to his fellow judges, he charged that the second judgment in particular had crossed the line, that it was "a textbook case of judicial overreach - a constitutionally impermissible intrusion by the Judiciary into the exclusive domain of Parliament". ${ }^{49}$

As such, instead of condemning the dissenting judgment as other quarters of the society clearly did, the Chief Justice's response should be commended for its concern for the separation of powers. It should be celebrated for providing insights into the fact that the judiciary - by criticizing itself - is sensitive to the need avoid descending into the legislature's policy formulation and political arena. Likewise, wanton intrusion into the role of the legislature would have negative externalities of it undermining the "public faith in the objectivity and detachment of the Court, without which the Court will be reduced to an impotent body, unable to perform those important, indeed vital functions which properly fall within its scope".50 Reiterating Kurland's warning Mogoeng Mogoeng counselled that the court's

... impartiality must therefore never be open to reasonable doubt. For, its moral authority without which it would cease to enjoy legitimate public confidence and ready compliance with its decisions by all, owes its existence to its predictable and self-evident execution of its mandate without any apparent fear, favour or prejudice. ${ }^{51}$

$47 \quad$ Okpaluba 2003 SAPR/PL 342.

48 Economic Freedom Fighters $v$ Speaker of the National Assembly 20182 SA 571 (CC).

49 Economic Freedom Fighters $v$ Speaker of the National Assembly 20182 SA 571 (CC) para 223.

$50 \quad$ Kurland 1959 Utah L Rev 457.

51 Economic Freedom Fighters $v$ Speaker of the National Assembly 20182 SA 571 (CC) para 235 
In essence therefore, Mogoeng Mogoeng's reasoning serves to arrest the potential risk of judicialisation of politics. Unlike its opposite - the politicisation of the judiciary, judicialisation of politics said to occurs when "the Court [assumes jurisdiction over] a wide variety of policy processes that would otherwise be the responsibility of the executive and legislature, that is, the majoritarian institutions". ${ }^{2}$ It is also characterized by a rising reliance "on judicial bodies and processes ... the reliance on courts and judicial processes to address 'core moral predicaments, public policy questions, and political controversies' and 'matters of outright and utmost political significance that often define and divide whole polities". ${ }^{53}$

Nonetheless, it is worth pointing out that in most cases the public has generally defended the judiciary and endeavours to demean the judiciary have not gone without censure and adverse publicity. ${ }^{54}$ Sympathy for the courts seems to be premised on the recognition that

... the jurisdiction of the courts must be jealously guarded if only for the reason that the beginning of dictatorships in many parts of the world had often commences with usurpations of authority of Courts and many dictators were often known to become restive under the procedural and structural safeguards employed by the Courts for the purpose of enhancing the rule of law and preserving the personal and propriety rights of individuals. ${ }^{55}$

Much as that might be so, expecting that tension to be eliminated would be idealistic. ${ }^{56}$ The consolation however, is that such antagonism can be reduced especially if the Executive and the judiciary both appreciate "that each has a role to perform and that each is better equipped to carry it out than the other ... that they are there to serve the people, not their own ends, and to adapt their conduct accordingly". ${ }^{57}$

Besides the risk of delegitimizing the judiciary, the government's anti-judicial review approach could have far-reaching consequences that undermine not just the authority of the courts but the economy as well. ${ }^{58}$ This is already a

52 Tate 1994 Int'l Pol Sci Rev 190

$53 \quad$ Ciencia "From Judicialization to Politicization of the Judiciary" 118.

54 See Van Zyl 2009 PELJ 2. See also Mattes et al 2003 http://www.afrobarometer.org/publications/wp24-democratic-governance-southafrica-peoples-view 2.

$55 \quad$ Aniagolu JSC in Oba Lamidi Adeyemi (Alafin of Oyo) \& Ors v Attorney General of Oyo State \& Ors 19841 SCNLR 525 602. See also Malila 2011 Zambia LJ 70.

56 McHugh 2002 http://www.hcourt.gov.au/assets/publications/speeches/formerjustices/mchughj/mchughj_paris.htm.

57 Pearce 1991 PLR 193.

58 It has been shown that there is a link between judicial independence and economic freedom or growth. See generally Epstein Economics of Judicial Behaviour; World Bank date unknown http://siteresources.worldbank.org/INTLAWJUSTIN ST/Resources/Judiciallndependence.pdf. In the South African context, it is reported that one of the considerations taken into account in averting a sovereign rating downgrade was the strength and independence of institutions such as the judiciary. 
problem, especially in light of the fact that the highest, the Constitutional Court enjoys "relatively low legitimacy, at least as compared to other high courts; its legitimacy varies across racial groups; and most important, that the Constitutional Court is able to convert its legitimacy into acquiescence only in some circumstances and only with some groups". ${ }^{59}$ Furthermore, the government's public statements might champion a perception that the judiciary is counter-majoritarian and partial. This might inter alia give ammunition to the government to interference in the appointment of judges. Emphasis would end up being put for instance, on ideological considerations when appointing judges which would result in a partisan bench.

It is probably in recognition of this sticky situation as well as the conundrums that come with the vilification of the courts that it was deemed necessary for the judiciary and the Executive to meet "to discuss matters of concern to the Judiciary. These included public utterances attributed to, among others, some members of the National Executive". ${ }^{60}$ This culminated in a with a "10point" agreement from which the executive and the judiciary agreed to cultivate mutual respect between each other. ${ }^{61}$ This is change of tone undoubtedly borrows from the understanding that "[w]hat we require if we are to move forward is an account that presents the legal and political constitutions not as competitors but as partners". ${ }^{2}$ However, judging by experience in other jurisdictions, such a resolution is imbued with skepticism. "The idea of a partnership may well provide a basis for the future relationship, but it would be unrealistic to expect it to be a partnership without tension."63 Added to that option, there should be a "model of

See for instance Fin24 2016 https:/www.fin24.com/Economy/sa-not-out-of-thewoods-on-ratings-downgrade-20160509; Joffe 2016 https://www.business live.co.za/bd/opinion/2016-12-07-institutional-strength-staved-off-junk-statusdowngrade-by-ratings-agencies/.

Gibson and Caldeira 2003 Journal of Politics 3. See also Hoexter 2000 SALJ 470; Daniels date unknown http://law.bepress.com/cgi/viewcontent.cgi? article=6279\&context=expresso; Hoexter Administrative Law; Corder, Jagwanth and Soltau 1999 http://www.casac.org.za/wp-content/uploads/2015/07/Report-onParliamentary-Oversight-and-Accountability.pdf; Pieterse 2004 SAJHR 388. South African Judiciary 2015 http://www.judiciary.org.za/index.php/news/pressstatements/statements-2015?start=20.

61 After the meeting, President Zuma read Zuma read out the following press statement: "The meeting agreed on the following: 1) our respect for the separation of powers and the integrity of the two institutions [executive and judiciary] 2) to exercise care and caution with regards to public statements and pronouncements criticising one another. Failure to do so will undermine the global status of the republic as a bastion of democracy, tolerance, human rights and the rule of law". South African Judiciary 2015 http://www.judiciary.org.za/index.php/news/pressstatements/statements-2015?start=20.

62 Hickman 2005 U Toronto LJ 1016.

63 House of Lords 2007 https://publications.parliament.uk/pa/ Id200607/ldselect/ldconst/151/151.pdf 68. 
separated powers that acknowledges the significance of both elements and identifies their proper place in a legitimate government structure". ${ }^{64}$

\section{Conclusion}

The foregoing examination of context-specific political attitudes toward judicial review is quite revealing. The reality is that for as long as judicial review is inherently or rendered political by virtue its intrinsic function - a function that extends their role beyond resolving particular legal disputes to one that shapes the boundaries of the political ${ }^{65}$ - fractious relationship between the judiciary and the other branches of government will endure. It is from this reality that the friction that has characterised the relationship between the South African judiciary and the other arms of the State should be understood.

That conflict is indicative or supports the supposition of entrenched political and legal constitutionalism. The common thread in the legislature and executive's reaction to judicial review decisions is that government supremacy is under threat from legal constitutionalism. That conflict however, arises more from the political effects of judicial review and not from legal reasoning upon which the judgments are based.

Furthermore, it should be noted that much as those two conflicting constitutionalism models have sought to elevate themselves above each other, the reality is that "purely legal and purely political constitutionalism both miss the very point of a constitution - to mutually reinforce the legal and political systems and to protect their differences".66 Fortunately, with the increased interactions between the executive and judiciary, it is hoped that accounts of hostilities culminating from the perceived judicialisation of the political arm can be minimised. That is a worthy start.

\section{Bibliography}

\section{Literature}

Arato 2012 ICON

Arato $\mathrm{J}$ "Constitutionality and Constitutionalism beyond the State: Two Perspectives on the Material Constitution of the United Nations" 2012 ICON 627-659

\footnotetext{
$64 \quad$ Mollers Three Branches 10.

65 Mendes 2010 CCR 33.

66 Mollers Three Branches 10. See also Rawls Theory of Justice
} 
Albertyn 2006 SAJHR

Albertyn C "Judicial Independence and the Constitution Fourteenth Amendment Bill" 2006 SAJHR 126-143

Bellamy Political Constitutionalism

Bellamy $\mathrm{R}$ Political Constitutionalism: A Republican Defence of the Constitutionality of Democracy (Cambridge University Press Cambridge 2007)

Carbonell Theory of New Constitutionalism

Carbonell M The Theory of New Constitutionalism (Iberoamericana Vervuert Madrid 2007)

Ciencia "From Judicialization to Politicization of the Judiciary"

Ciencia AN "From Judicialization to Politicization of the Judiciary: The Philippine Case" in Dressel B (ed) The Judicialization of Politics in Asia (Routledge London 2012) 117-138

Cohen "Sovereignty in the Context of Globalization"

Cohen $\mathrm{J}$ "Sovereignty in the Context of Globalization: A Constitutional Pluralist Perspective" in Besson S and Tasioulas J (eds) The Philosophy of International Law (Oxford University Press Oxford 2010) 261-280

Craig "Political Constitutionalism and Judicial Review"

Craig P "Political Constitutionalism and Judicial Review" in Forsyth $\mathrm{C}$ et al (eds) Effective Judicial Review: A Cornerstone of Good Governance (Oxford University Press Oxford 2010) 19-42

Craig 2011 ICON

Craig P "Political Constitutionalism and the Judicial Role: A Response" 2011 ICON 112-131

Dawson, Enderlein and Joerges Beyond the Crisis

Dawson M, Enderlein $\mathrm{H}$ and Joerges $\mathrm{C}$ Beyond the Crisis: The Governance of Europe's Economic, Political and Legal Transformation (Oxford University Press Oxford 2016)

Dodek 2009 JPPL

Dodek A "State $v$ Zuma: The Future of Constitutional Democracy in South Africa" 2009 JPPL 121-128

Epstein Economics of Judicial Behaviour

Epstein L (ed) The Economics of Judicial Behaviour Volume I (Edward Elgar Cheltenham 2013) 
European Commission for Democracy through Law Definition and Development of Human Rights

European Commission for Democracy through Law Definition and Development of Human Rights and Popular Sovereignty in Europe (Council of Europe Strasbourg 2011)

Feiyue 2006 Front Law China

Feiyue $S$ "Economic Constitutionalism: Path for State to Intervene in the Economy" 2006 Front Law China 372-392

Gee and Webber 2010 OJLS

Gee $\mathrm{G}$ and Webber GCN "What is a Political Constitution?" 2010 OJLS 273299

Gerber 2001 JITE

Gerber DJ "Economic Constitutionalism and the Challenge of Globalization: The Enemy is Gone? Long Live the Enemy: Comment" 2001 JITE 14-22

Gibson and Caldeira 2003 Journal of Politics

Gibson JL and Caldeira GA "Defenders of Democracy? Legitimacy, Popular Acceptance and the South African Constitutional Court" 2003 Journal of Politics 1-30

Goldoni 2012 ICON

Goldoni M "Two Internal Critiques of Political Constitutionalism" 2012 ICON 926-949

Griffith 1979 MLR

Griffith JAG "The Political Constitution" 1979 MLR 1-21

Gumede Restless Nation

Gumede WM Restless Nation: Making Sense of Troubled Times (Tafelberg Cape Town 2012)

Hickman 2005 U Toronto LJ

Hickman T "In Defence of the Legal Constitution" 2005 U Toronto LJ 9811022

Hirschl 2006 Fordham L Rev

Hirschl R "The New Constitutionalism and the Judicialization of Politics Worldwide" 2006 Fordham L Rev 721-754

Hoexter 2000 SALJ

Hoexter C "The Future of Judicial Review in South African Administrative Law" 2000 SALJ 484-519 
Hoexter Administrative Law

Hoexter C Administrative Law in South Africa $2^{\text {nd }}$ ed (Juta Cape Town 2012)

Honohan "Republicans, Rights, and Constitutions"

Honohan I "Republicans, Rights, and Constitutions: Is Judicial Review Compatible with Republican Self-government?" in Besson S and Martí JL (eds) Legal Republicanism: National and International Perspectives (Oxford University Press Oxford 2009) 83-101

Horowitz "Constitutional Design"

Horowitz DL "Constitutional Design: Proposals versus Processes" in Reynolds A (ed) The Architecture of Democracy (Oxford University Press New York 2002) 15-36

Klug 2010 CCR

Klug $\mathrm{H}$ "Finding the Constitutional Court's Place in South Africa's Democracy: The Interaction of Principle and Institutional Pragmatism in the Court's Decision Making" 2010 CCR 1-32

Kurland 1959 Utah L Rev

Kurland PB "The Supreme Court and Its Judicial Critics" 1959 Utah L Rev 457-466

Malila 2011 Zambia LJ

Malila M "The Zambian Judiciary on Trial: Politicisation of the Judiciary or Judicialisation of Politics?" 2011 Zambia LJ 63-152

Mendes 2010 CCR

Mendes $\mathrm{CH}$ "Fighting for their Place: Constitutional Courts as Political Actors - A Reply to Heinz Klug" 2010 CCR 33-43

Mollers Three Branches

Mollers C The Three Branches: A Comparative Model of Separation of Powers (Oxford University Press Oxford 2013)

Moseneke 2012 SALJ

Moseneke D "Striking a Balance between the Will of the People and the Supremacy of the Constitution" 2012 SALJ 9-22

Okpaluba 2003 SAPR/PL

Okpaluba C "Justiciability, Constitutional Adjudication and the Political Question in a Nascent Democracy: South Africa (Part 1)" 2003 SAPR/PL 331-348

Pearce 1991 PLR

Pearce D "Executive Versus Judiciary" 1991 PLR 179-193 
Pieterse 2004 SAJHR

Pieterse $M$ "Coming to Terms with the Judicial Enforcement of SocioEconomic Rights" 2004 SAJHR 383-417

Rawls Theory of Justice Rawls J A Theory of Justice (Harvard University Press Cambridge 1971)

Sciulli Theory of Societal Constitutionalism

Sciulli D Theory of Societal Constitutionalism: Foundations of a Non-Marxist Critical Theory (Cambridge University Press Cambridge 1992)

Shinar Accidental Constitutionalism

Shinar A Accidental Constitutionalism: The Political Foundations and Implications of Constitution-Making in Israel (Cambridge University Press Cambridge 2013)

Siyo et al 2015 PELJ

Siyo L and Mubangizi JC "The Independence of South African Judges: A Constitutional and Legislative Perspective" 2015 PELJ 816-846

Tate 1994 Int'l Pol Sci Rev

Tate C. Neal "The Judicialization of Politics in the Philippines and Southeast Asia" 1994 Int'l Pol Sci Rev187-197

Tomkins $2010 U$ Toronto $L J$

Tomkins A "The Role of the Courts in the Political Constitution" $2010 \mathrm{U}$ Toronto LJ 1-22

Tushnet 2006 Chi-Kent L Rev

Tushnet MV "Popular Constitutionalism as Political Law" 2006 Chi-Kent L Rev 991-1007

Vinx 2010 Political Theory

Vinx L "Constitutional Indifferentism and Republican Freedom" 2010 Political Theory 809-837

Waldron 2006 Yale LJ

Waldron $\mathrm{J}$ "The Core of the Case against Judicial Review" 2006 Yale LJ 1346-1360

Walen 2009 ICON

Walen A "Judicial Review in Review: A Four-Part Defense of Legal Constitutionalism" 2009 ICON 329-354 
Van Zyl 2009 PELJ

Van Zyl D "The Judiciary as a Bastion of the Legal Order in Challenging Times" 2009 PELJ 1-13

Vibert New Regulatory Space

Vibert F The New Regulatory Space: Reframing Democratic Governance (Edward Elgar Cheltenham 2014)

Vinx 2010 Political Theory

Vinx L "Constitutional Indifferentism and Republican Freedom" 2010 Political Theory 809-837

\section{Case law}

Doctors for Life International v Speaker of the National Assembly 20066 SA 416 (CC)

Economic Freedom Fighters $v$ Speaker of the National Assembly 20182 SA $571(\mathrm{CC})$

Freedom under Law v Acting Chairperson: Judicial Service Commission 20113 SA 549 (SCA)

Glenister v President of the Republic of South Africa 2011 3 SA 347 (CC)

Government of the Republic of South Africa v Grootboom 20011 SA 46 (CC)

Hlophe v Constitutional Court of South Africa 2008 ZAGPHC 289 (25 September 2008)

Primedia Broadcasting, A Division of Primedia (Pty) Ltd $v$ Speaker of the National Assembly 20154 SA 525 (WCC)

Minister of Health v Treatment Action Campaign 20025 SA 721 (CC)

Minister of Justice and Constitutional Development $v$ The Southern African Litigation Centre 2016 ZASCA 17 (15 March 2016)

Oba Lamidi Adeyemi (Alafin of Oyo) \& Ors v Attorney General of Oyo State \& Ors 19841 SCNLR 525

S v Makwanyane 19953 SA 391 (CC)

S v Zuma 20062 SACR 191 (W) 


\section{Legislation}

Constitution of the Republic of South Africa, 1996

\section{Internet sources}

Bellamy $2007 \quad$ https://www.ucl.ac.uk/spp/research/publications/ downloads/SPP-WP-26-Inaugural-Lecture.pdf

Bellamy R 2007 Inaugural Lecture: Political Constitutionalism https://www.ucl.ac.uk/spp/research/publications/downloads/SPP-WP-26Inaugural-Lecture.pdf accessed 11 September 2016

Britton 2015 http://702.co.za/articles/3355/gwede-mantashe-the-judiciaryhas-anti-government-tendencies

Britton N 2015 Gwede Mantashe: The Judiciary has Anti-government Tendencies http://702.co.za/articles/3355/gwede-mantashe-the-judiciaryhas-anti-government-tendencies accessed 7 November 2016

Budlender 2011 http://www.polity.org.za/article/sa-budlender-address-byhuman-rights-lawyer-at-the-bram-fischermemorial-lecture-johannesburg11112011-2011-11-11

Budlender G 2011 Bram Fischer Memorial Lecture, 11 November 2011 http://www.polity.org.za/article/sa-budlender-address-by-human-rightslawyer-at-the-bram-fischermemorial-lecture-johannesburg-111120112011-11-11 accessed 10 October 2016

Comrie 2015 https://www.news24.com/SouthAfrica/News/GwedeMantashe-singles-out-problematic-courts-20150622

Comrie S 2015 Gwede Mantashe Singles out 'Problematic Courts' https://www.news24.com/SouthAfrica/News/Gwede-Mantashe-singles-outproblematic-courts-20150622 accessed 17 April 2018

Corder, Jagwanth and Soltau 1999 http://www.casac.org.za/wpcontent/uploads/2015/07/Report-on-Parliamentary-Oversight-and-

Accountability.pdf

Corder H, Jagwanth S and Soltau F 1999 Report on Parliamentary Oversight and Accountability http://www.casac.org.za/wpcontent/uploads/2015/07/Report-on-Parliamentary-Oversight-and-

Accountability.pdf accessed 21 October 2016

Dani 2009 http://www.Ise.ac.uk/european-institute/Assets/Documents/ LEQS-Discussion-Papers/LEQSPaper13b.pdf

Dani M 2009 Economic and Social Conflicts, Integration and Constitutionalism in Contemporary Europe http://www.Ise.ac.uk/european- 
institute/Assets/Documents/LEQS-Discussion-Papers/LEQSPaper13b.pdf accessed 30 November 2016

Daniels date unknown http://law.bepress.com/cgi/viewcontent. cgi?article $=6279 \&$ context $=$ expresso

Daniels $\mathrm{R}$ date unknown The Counter-Majoritarian Difficulty and the South African Constitutional Court http://law.bepress.com/cgi/viewcontent. cgi?article $=6279 \&$ context $=$ expresso accessed 30 October 2016

Democratic Governance and Rights Unit 2014 http://www.dgru.uct.ac.za/sites/default/files/image_tool/images/103/Separa tion\%20of\%20Powers\%20Draft\%20August\%202014.pdf

Democratic Governance and Rights Unit 2014 Has the South African Constitutional Court Over-Reached? A Study of the Court's Application of the Separation of Powers Doctrine between 2009 and 2013 http://www.dgru.uct.ac.za/sites/default/files/image_tool/images/103/Separa tion\%20of\%20Powers\%20Draft\%20August\%202014.pdf accessed 7 November 2016

eNCA 2015 https://www.enca.com/south-africa/gwede-mantashe-criticisesjudiciary-being-problematic

eNCA 2015 Gwede Mantashe Criticises Judiciary as Being Problematic https://www.enca.com/south-africa/gwede-mantashe-criticises-judiciarybeing-problematic accessed 17 November 2016

Fin24 2016 https://www.fin24.com/Economy/sa-not-out-of-the-woods-onratings-downgrade-20160509

Fin24 2016 SA not out of the Woods on Ratings Downgrade https://www.fin24.com/Economy/sa-not-out-of-the-woods-on-ratingsdowngrade-20160509 accessed 17 April 2018

Hartley $2011 \quad$ https://www.pressreader.com/south-africa/businessday/20111102/282480000577522

Hartley W 2011 "Executive Superior to Courts, Says Zuma" Business Day (2 November 2011) https://www.pressreader.com/south-africa/businessday/20111102/282480000577522 accessed 17 April 2018

House of Lords 2007 https://publications.parliament.uk/pa/ld200607/ Idselect/ldconst/151/151.pdf

House of Lords 2007 Relations between the Executive, the Judiciary and Parliament: Report with Evidence. 6th Report of Session 2006-07 https://publications. parliament.uk/pa/ld200607/ldselect/ldconst/151/151.pdf accessed 17 April 2018 
Joffe $2016 \quad$ https://www.businesslive.co.za/bd/opinion/2016-12-07institutional-strength-staved-off-junk-status-downgrade-by-ratingsagencies/

Joffe H 2016 Institutional Strength Staved off Junk Status Downgrade by Ratings Agencies https://www.businesslive.co.za/bd/opinion/2016-12-07institutional-strength-staved-off-junk-status-downgrade-by-ratingsagencies/ accessed 17 April 2018

Klaaren 2009 http://wiredspace.wits.ac.za/jspui/bitstream/10539/ 8749/1/Hlophe\%20and\%20the\%20Politics\%20of\%20the\%20Judiciary.pdf Klaaren J 2009 Hlophe JP and the Current Politics of the South African Judiciary

http://wiredspace.wits.ac.za/jspui/bitstream/10539/8749/1/Hlophe\%20and \%20the\%20Politics\%20of\%20the\%20Judiciary.pdf accessed 27 November 2016

Legalbrief Today $2011 \quad \mathrm{http}: / /$ legalbrief.co.za/diary/legalbrieftoday/story/zuma-lays-down-law-on-separation-of-powers/print/ Legalbrief Today 2011 Zuma Lays Down Law on Separation of Powers http://legalbrief.co.za/diary/legalbrief-today/story/zuma-lays-down-law-onseparation-of-powers/print/ accessed 29 August 2016

Letsoalo, Rossouw and Alcock 2008 https://mg.co.za/article/2008-07-04anc-boss-accuses-judges-of-conspiracy-against-zuma

Letsoalo M, Rossouw M and Alcock SS 2008 "ANC boss accuses judges of conspiracy against Zuma" Mail and Guardian (4 July 2008) https://mg.co.za/article/2008-07-04-anc-boss-accuses-judges-ofconspiracy-against-zuma accessed 17 April 2018

Mattes et al 2003 http://www.afrobarometer.org/publications/wp24democratic-governance-south-africa-peoples-view Mattes R et al 2003 Democratic Governance in South Africa: The People's View (Afrobarometer Paper No 24) http://www.afrobarometer.org/ publications/wp24-democratic-governance-south-africa-peoples-view accessed 15 April 2018

McHugh 2002 http://www.hcourt.gov.au/assets/publications/speeches/ former-justices/mchughj/mchughj_paris.htm

McHugh AC 2002 Tensions between the Executive and the Judiciary http://www.hcourt.gov.au/assets/publications/speeches/formerjustices/mchughj/mchughj_paris.htm accessed 2 December 2016 
News24 $2011 \quad$ http://m.news24.com/news24/SouthAfrica/Politics/ Nzimande-slams-judicial-dictatorship-20111217-2

News24 2011 Nzimande Slams 'Judicial Dictatorship' http://m.news24.com/news24/SouthAfrica/Politics/Nzimande-slamsjudicial-dictatorship-20111217-2 accessed 2 December 2016

South African Judiciary 2015 http://www.judiciary.org.za/index.php/news/ press-statements/statements-2015?start $=20$

South African Judiciary 2015 Statement on the Meeting of the National Executive and the Judiciary, Union Buildings - Pretoria, 27 August 2015 http://www.judiciary.org.za/index.php/news/press-statements/statements2015?start=20 accessed 19 April 2018

World Bank date unknown http://siteresources.worldbank.org/ INTLAWJUSTINST/Resources/Judiciallndependence.pdf World Bank date unknown Judicial Independence: What It Is, How It Can Be Measured, Why It Occurs http://siteresources.worldbank.org/ INTLAWJUSTINST/Resources/Judiciallndependence.pdf accessed 12 December 2016

\section{List of Abbreviations}

ANC

CCR

Chi-Kent L Rev

Fordham L Rev

Front Law China

ICON

Int'I Pol Sci Rev

JITE

$J P P L$

JSC

MLR

NC L Rev

NW U L Rev

NYU L Rev

OJLS

PELJ

PLR

SACP

SAJHR

SALJ

SAPR/PL
African National Congress

Constitutional Court Review

Chicago-Kent Law Review

Fordham Law Review

Frontiers of Law in China

International Journal of Constitutional Law

International Political Science Review

Journal of Institutional and Theoretical

Economics

Journal of Parliamentary and Political Law

Judicial Service Commission

Modern Law Review

North Carolina Law Review

Northwest University Law Review

New York University Law Review

Oxford Journal of Legal Studies

Potchefstroom Electronic Law Journal

Public Law Review

South African Communist Party

South African Journal of Human Rights

South African Law Journal

South Afrikaanse Publiekreg / Public Law 
St Louis U Pub L Rev

U Toronto LJ

Utah L Rev

Yale LJ

Zambia LJ
Saint Louis University Public Law Review University of Toronto Law Journal Utah Law Review

Yale Law Journal

Zambia Law Journal 